\title{
Response of drip irrigated Broccoli (Brassica oleracea var. italica) in different irrigation levels and frequencies at field level
}

\author{
Arti Kumari ${ }^{1 *}$, Neelam Patel $^{2}$ and A. K. Mishra ${ }^{2}$ \\ ${ }^{1}$ Division of Agricultural Engineering, ICAR-Indian Agricultural Research Institute, New Delhi-110012, INDIA \\ ${ }^{2}$ Water Technology Centre, ICAR-Indian Agricultural Research Institute, New Delhi-110012, INDIA \\ *Corresponding author. E-mail:kumariarti995@gmail.com \\ Received: April 2, 2017; Revised received: July 17, 2017; Accepted: April 5, 2018
}

\begin{abstract}
Geometric increase in population coupled with rapid urbanization, industrialization and agricultural development are causing increased pressure on global water resources. Agriculture is the largest consumer of fresh water resources, thus the scope of enhancing water productivity in agriculture is taken to be the priority area of research. The right amount and frequency of irrigation is essential for optimum use of limited water resources for crop production as well as management. A field experiment with split plot design was carried out during November to February 2015-16 at PFDC (Precision Farming Development Centre), Water Technology Centre, IARI, New Delhi to study the effect of different irrigation levels and frequencies on Broccoli (Brassica oleracea var. italica) under drip irrigation. The experiment included three levels of irrigation frequencies: $\mathrm{N}_{1}$ (once every day), $\mathrm{N}_{2}$ (once every 2 days) and $\mathrm{N}_{3}$ (once every 3 days) with different irrigation levels of 100,80 and $60 \%$ of crop evapotranspiration $\left(E T_{c}\right)$. Results revealed that drip irrigation frequency significantly $(p<0.05)$ affected the broccoli yield. The maximum yield $(24.46 \pm 0.18 \mathrm{t} / \mathrm{ha})$ was obtained with $80 \%$ of $\mathrm{ET}_{\mathrm{c}}$ with once in 2 days irrigation followed by $100 \%$ of $\mathrm{ET}_{\mathrm{c}}$ with once in 2 days. Lowest yield $(16.53 \pm 0.1 \mathrm{t} / \mathrm{ha})$ was obtained at $60 \%$ of $E T_{\mathrm{c}}$ at once in 3 days irrigation. Overall, it was observed that irrigation on $80 \%$ of $\mathrm{ET}_{\mathrm{c}}$ with once in two days is an appropriate cycle for optimum yield of broccoli.
\end{abstract}

Keywords: Broccoli yield, Crop evapotranspiration $\left(\mathrm{ET}_{\mathrm{c}}\right)$, Drip irrigation, Field capacity, Irrigation scheduling

\section{INTRODUCTION}

In Indian scenario, by 2030, water demand will grow to almost 1500 billion $\mathrm{m}^{3}$, driven by demand for growing food grain to feed the burgeoning population growth. India's current water supply is about 740 billion $\mathrm{m}^{3}$, which necessitates implementation of judicious water management technologies to enhance crop water productivity.

Agriculture is the major consumer of water which consumes around $80 \%$ of our country's available water resources (Anonymous, 2013). In India, about 83\% of water is used in irrigation and the remaining for domestic, industrial and other purposes (TERI, 2015). Irrigation water is becoming scarce due to depletion of surface and subsurface water. Land and Water productivity (LWP) can be enhanced with proper irrigation scheduling, judicious soil nutrient management and proper use of technologies pertaining to soil moisture storage within crop root zone up to field capacity (Andrade et al., 2001). The management of the irrigation is primarily based on when and how much water is to be applied to field as per crop water need. Recently, Soil moisture sensor based irrigation scheduling is performed through wireless networks and accessed using web browser or smartphone apps (Chan et al.
2017).Irrigation Scheduling is important for environmental quality by reducing chemical percolation and nutrient loss in the soil, and in achieving crop specific water requirements, which would help the irrigators (Leib et. al., 2002; Soulis et al., 2015). Several studies have been carried out in past elsewhere on improvement and assessment of irrigation scheduling techniques. Appropriate irrigation scheduling saves both water and energy. Broccoli (Brassica oleracea var. italica) is also a Cole crop and is known to be hearty and tasty vegetable which is rich in several nutrients like vit- $\mathrm{C}$, vit-K, iron, protein etc. It also called as "crown of jewel nutrition" because it is rich in protein ( $29 \%$ of its dry wt.) and minerals. After lettuce, Broccoli is the most important vegetable widely known for anticancer health benefits to human health (Brennan et al., 2016). Tolga Erdem et al. (2010) conducted experiments on broccoli crop to evaluate the yield and quality of broccoli under different irrigation regimes, nitrogen applications and cultivation periods resulted in obtaining the highest yield in the spring crop (11.02 t/ ha) followed with the autumn crop (4.55 t/ha). Further, an experiment to evaluate the response of broccoli to irrigation scheduling and methods under drip, sprinkler and surface irrigation was carried out by Himanshu et 
al. (2013) and observed that that to obtain higher marketable yield and net return under semi-arid climate, the crop should be irrigated at $150-160 \%$ of pan evaporation replenishment with drip or micro sprinkler irrigation system. The effect of different levels of supplemental irrigation $(1 / 3,2 / 3$ and full) and nitrogen rates (i.e. $0,30,60,90$ and $120 \mathrm{~kg} / \mathrm{ha}$ ) on the grain yield of rain fed wheat cv. Sabalan was examined by Tavakkoli and Oweis (2004) and found that the optimum level of supplemental irrigation was with $1 / 3$ of full supplemental irrigation recording the maximum water productivity and crop response significant up to $60 \mathrm{~kg} /$ ha.An experiment was carried out on cultivation of onion seed on sandy clay loam soil during rabi season to study the influence of micro irrigation and fertilizers levels through fertigation on growth, yield and quality by Bhakare et al. (2008). They found that there was saving of $39.9 \%$ irrigation water through drip system compared to surface irrigation. Although, consolidated efforts were made to review the work done by various workers on the effect of different irrigation levels and frequency on irrigation scheduling and related aspects of crop water management but there were only a few references pertaining to the broccoli crop.

For appropriate understanding of effect of different irrigation regimes, research is needed on sensor based drip system to recognize the best strategy of irrigation. Keeping in view of the above findings and suggestions on enhancing productivity, an experiment was undertaken to study the effect of different irrigation levels and frequencies on Broccoli (Brassica oleracea var. italica) under drip irrigation.

\section{MATERIALS AND METHODS}

Site description: The experimental field is located in the research farm of Water Technology Centre, Indian Agricultural Research Institute (IARI), New Delhi. The research farm's soil was sandy loam in texture (65.8\% sand, $13.8 \%$ silt and $20.45 \%$ clay) and belongs to Mehrauli series. IARI farm is situated in between the latitudes of $28^{\circ} 37^{\prime} 22^{\prime} \mathrm{N}$ and $28^{\circ} 39^{\prime} 05^{\prime \prime} \mathrm{N}$ and longitudes of $77^{\circ} 8$ ' $45^{\prime \prime}$ and $77^{\circ} 10^{\prime} 24$ 'E, at mean elevation of $230 \mathrm{~m}$ above sea level. The climate of New Delhi, India is semi-arid and sub-tropical with dry and hot summers and cold winters and falls under the agroclimatic zone of "Trans-Gangetic plains". Climate data during the experiment period was obtained from the observatory located adjacent to the experimental site. Temperature and rainfall depth during the crop growth period 2015-16 is presented in Figs. 1 and 2, respectively.

Field layout and treatment levels: The experiment was conducted on a field having dimensions of $29 \mathrm{~m} \mathrm{x}$ $15 \mathrm{~m}$ during November to February 2015-16. The total area of the field was $435 \mathrm{~m}^{2}$. The field was divided into three equal parts each of $9 \mathrm{~m} \times 15 \mathrm{~m}$. The buffer strip of $1 \mathrm{~m}$ was maintained in between the two plots for separating one plot from another. The main and sub -main lines were laid on the buffer strip. Each plot was irrigated using $16 \mathrm{~mm}$ diameter of 9 laterals having drippers' discharge $2 \mathrm{lph}$ at spacing of $50 \mathrm{~cm}$. Every plot consists of different treatments. The experiment was planned with 9 treatments and 3 replications following a split plot design (fig.3). Three different irrigation levels of 60,80 and $100 \%$ of crop evapotranspiration $\left(\mathrm{ET}_{\mathrm{c}}\right)$ and three irrigation frequencies with daily irrigation $\left(\mathrm{N}_{1}\right)$, once in 2 days irrigation $\left(\mathrm{N}_{2}\right)$ and once in 3 days irrigation $\left(\mathrm{N}_{3}\right)$ were maintained in the crop. Soil moisture sensors namely FDR were installed in one replication of each treatment at different depth up to $60 \mathrm{~cm}$. A separate data logger attached to the FDR was used to download, store the data and then transferred to a computer for interpretation using software developed by EnviroScan. The treatments considered in the study are given below:

$\mathrm{T}_{1}: 100 \%$ water requirement of $\mathrm{ET}_{\mathrm{c}}$ with daily irrigation

$\mathrm{T}_{2}: 80 \%$ water requirement of $\mathrm{ET}_{\mathrm{c}}$ with daily irrigation $\mathrm{T}_{3}: 60 \%$ water requirement of $\mathrm{ET}_{\mathrm{c}}$ with daily irrigation $\mathrm{T}_{4}: 100 \%$ water requirement of $\mathrm{ET}_{\mathrm{c}}$ with irrigation once in 2 days

$\mathrm{T}_{5}: 80 \%$ water requirement of $\mathrm{ET}_{\mathrm{c}}$ with irrigation once in 2 days

$\mathrm{T}_{6}: 60 \%$ water requirement of $\mathrm{ET}_{\mathrm{c}}$ with irrigation once in 2 days

$\mathrm{T}_{7}: 100 \%$ water requirement of $\mathrm{ET}_{\mathrm{c}}$ with irrigation once in 3 days

$\mathrm{T}_{8}: 80 \%$ water requirement of $\mathrm{ET}_{\mathrm{c}}$ with irrigation once in 3 days

$\mathrm{T}_{9}: 60 \%$ water requirement of $\mathrm{ET}_{\mathrm{c}}$ with irrigation once in 3 days

The broccoli seeds were propagated in a nursery bed in the first week of October, 2015. Broccoli seedlings were transplanted to the plot on the $7^{\text {th }}$ November, 2015 at a plant to plant and row to row spacing $30 \mathrm{~cm}$, respectively.

Data acquisition from the experiment: The soil samples were collected from different levels of soil from surface up to depth of $60 \mathrm{~cm}$ using tube auger. These samples were analyzed for determining the basic physical properties of soil such as distribution of particle size, soil texture, soil moisture (\%), hydraulic conductivity $(\mathrm{cm} / \mathrm{h})$, bulk density $\left(\mathrm{g} / \mathrm{cm}^{3}\right)$, field capacity and permanent wilting point $(\%)$. Details of the physical properties of soil are given in table 1 .

Irrigation scheduling in the experiment: Irrigation water was applied based on soil moisture deficit irrigation scheduling to bring the soil moisture content in root zone up to field capacity $\mathrm{f}$ on the date of irrigation. For this purpose, the moisture content of soil profile up to the root zone depth was measured by Frequency Domain Reflectometer (FDR). Irrigation date was decided based on Maximum allowable deficit (MAD) value. Quantity of irrigation water on volume basis applied to each treatment was calculated using 
the equation given below,

$\mathrm{V}$ (1) $=\frac{F \cdot C_{\mathrm{o}}-M C_{\mathrm{bi}}}{100} \times B . D . \times R Z D \times A \times 1000 \ldots \ldots q n(1)$

Where, V (1): volume of water in litre;

F.C.: Field capacity (\%)

$\mathrm{MC}_{\mathrm{bi}}$ : Moisture content before irrigation (\%);

B.D: bulk density (g/cc);

RZD: root zone depth (m);

A: area of each plot $\left(\mathrm{m}^{2}\right)$

Statistical analysis: The data was analyzed using procglm module of SAS version 9.3 software. The significance test of null hypothesis of equality of mainplot treatment effects and sub-plot treatment effects were tested from analysis of variance (ANOVA) estimation. The critical difference (CD) for estimated treatment contrasts were worked out using standard statistical procedures. The mean difference of treatments was compared with $\mathrm{CD}$ value and the treatments with higher effect over others were identified.

\section{RESULTS AND DISCUSSION}

Irrigation water requirement: The daily water requirement of broccoli crop was calculated on the basis of reference crop evapo-transpiration $\left(\mathrm{ET}_{\mathrm{o}}\right)$ by using Penman-Monteith's semi-empirical formula (Allen et.al. 1998). The water requirement of broccoli varied from 1.63 to $4.1 \pm 0.45 \mathrm{~mm} /$ day from early stage to peak demand period in 75-90 days after sowing. The estimated weekly $\mathrm{ET}_{\mathrm{c}}$ are presented in fig.4. The duration of operation of drip system was determined for different levels of irrigation. The duration of irrigation $\left(10,8\right.$ and 6 min for 100,80 and $\left.60 \% \mathrm{ET}_{\mathrm{c}}\right)$ in each treatment was controlled with the help of control valves.

Effect of irrigation regimes on broccoli yield: Broccoli yield (kg/ha) was decreased with decreasing amount of applied irrigation water. It was observed

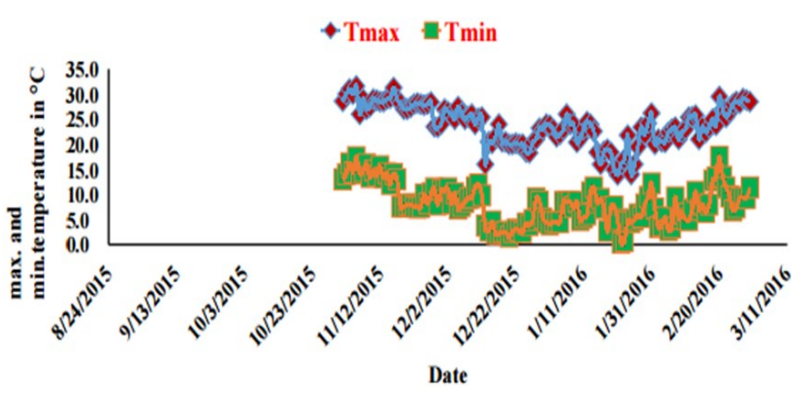

Fig.1. Variation of maximum and minimum temperature during the crop growing season (Agricultural Physics Dept. IARI).

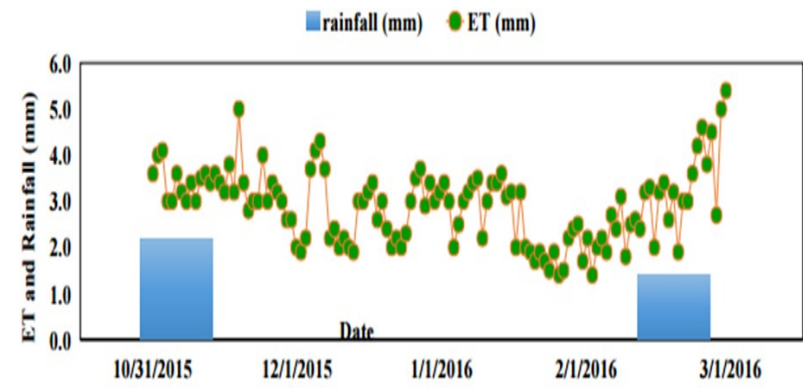

Fig.2. Variation of rainfall $(\mathrm{mm})$ and ET during the crop season (broccoli).

that the maximum yield $(24.46 \pm 0.18 \mathrm{t} / \mathrm{ha})$ was obtained with $80 \%$ of $\mathrm{ET}_{\mathrm{c}}$ with once in 2 days irrigation followed by $100 \%$ of $\mathrm{ET}_{\mathrm{c}}$ with once in 2 days. Lowest yield $(16.53 \pm 0.1 \mathrm{t} / \mathrm{ha})$ was obtained at $60 \%$ of $\mathrm{ET}_{\mathrm{c}}$ at once in 3 days irrigation (Fig. 5). These results were confirmative with Thentu et al.(2016) who found that drip irrigation at $0.8 \mathrm{ET}_{\mathrm{c}}$ showed significantly higher $(\mathrm{P}=0.05)$ marketable curd yield $(17.82 \mathrm{t} / \mathrm{ha})$ of broccoli, which was at par with drip at $1.0 \mathrm{ET}_{\mathrm{c}}$. Minimum growth and yield was obtained with drip irrigation at $0.6 \mathrm{ET}_{\mathrm{c}}$ in both the years. Bora et al. (2014) also revealed that drip irrigation at $80 \%$ evapo-

Table 1. Physical properties of the soil of PFDC, WTC.

\begin{tabular}{|c|c|c|c|c|c|c|c|c|}
\hline \multirow{2}{*}{$\begin{array}{l}\text { Depth } \\
\text { (cm) }\end{array}$} & \multicolumn{3}{|c|}{ Particle size distribution (\%) } & \multirow{2}{*}{$\begin{array}{l}\text { Textural } \\
\text { class }\end{array}$} & \multirow{2}{*}{$\begin{array}{l}\text { Hydraulic con- } \\
\text { ductivity }(\mathrm{cm} / \mathrm{h})\end{array}$} & \multirow{2}{*}{$\begin{array}{l}\text { Bulk den- } \\
\text { sity }\left(\mathrm{g} / \mathrm{cm}^{3}\right)\end{array}$} & \multirow{2}{*}{$\begin{array}{l}\text { Field ca- } \\
\text { pacity }(\%)\end{array}$} & \multirow{2}{*}{$\begin{array}{l}\text { Permanent } \\
\text { wilting poin(\%) }\end{array}$} \\
\hline & Sand & Silt & Clay & & & & & \\
\hline $0-15$ & 67.28 & 14.72 & 18.0 & Sandy loam & 1.65 & 1.63 & 17.42 & 7.78 \\
\hline $15-30$ & 65.6 & 13.7 & 20.7 & Sandy loam & 1.12 & 1.48 & 19.65 & 9.10 \\
\hline $30-45$ & 65.4 & 13.2 & 21.4 & Sandy loam & 1.06 & 1.48 & 18.16 & 10.36 \\
\hline $45-60$ & 64.8 & 13.5 & 21.7 & Sandy loam & 1.55 & 1.61 & 18.22 & 10.71 \\
\hline Avg. & 65.77 & 13.78 & 20.45 & Sandy loamy & 1.345 & 1.55 & 18.36 & 9.49 \\
\hline
\end{tabular}

Table 2. ANOVA for effect of irrigation frequencies on broccoli yield.

\begin{tabular}{|c|c|c|c|c|c|}
\hline Source of variation & Df & S.S. & M.S. & F-value & p-value \\
\hline Replication & 2 & 0.607 & 0.304 & 2.94 & 0.0624 \\
\hline $\begin{array}{l}\text { Main plot treatment (irrigation fre- } \\
\text { quencies) }\end{array}$ & 2 & 145.339 & 72.669 & 704.28 & $<.0001$ \\
\hline Error & 4 & 1.478 & 0.369 & 3.58 & 0.0124 \\
\hline Source of variation & Df & S.S. & M.S. & F-value & p-value \\
\hline Replication & 2 & 0.607 & 0.303 & 2.94 & 0.0624 \\
\hline Subplot treatment (amount of water) & 8 & 12.665 & 1.583 & 15.34 & $<.0001$ \\
\hline Error & 16 & 4.536 & 0.283 & 2.75 & 0.0035 \\
\hline
\end{tabular}




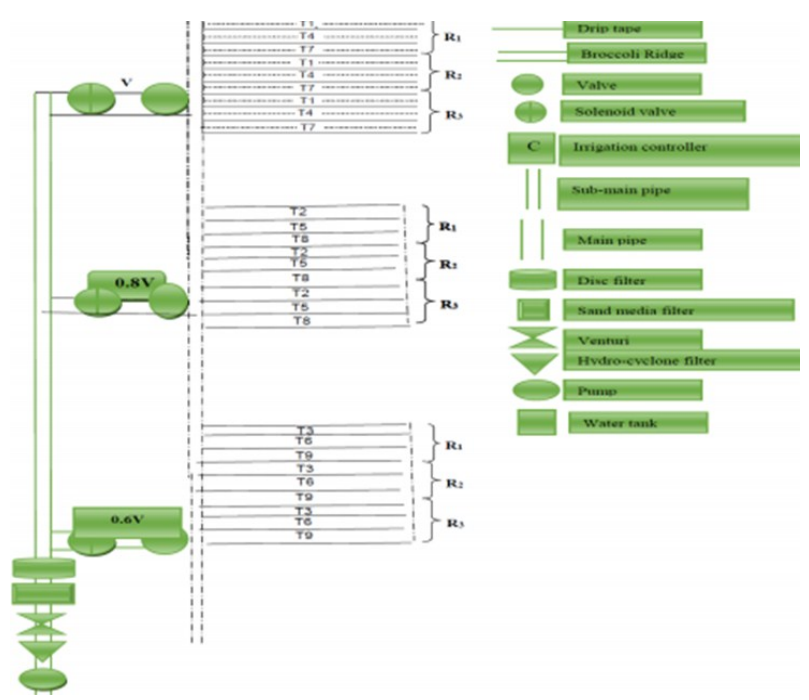

Fig. 3. Layout of the experimental field (Split Plot Design).

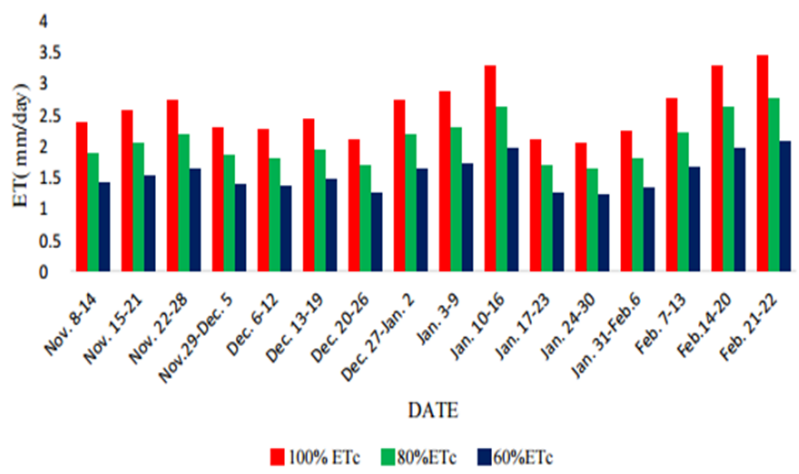

Fig.4. Weekly ETc of broccoli during entire growing period.

transpiration (ET) of crop based on pan evaporation gave significantly higher fruit yield (45.57 t/ha) compared with the surface irrigation in tomato crop on sandy loam soils of Punjab, India. The average yield of broccoli was recorded as 20.01 \pm 0.1 , $23.27 \pm 0.3$ and $20.86 \pm 0.15 \mathrm{t} / \mathrm{ha}$ for daily irrigation, once in 2 and 3 days irrigation frequency, respectively. Crop was irrigated by using inline drip system having emitters at $40 \mathrm{~cm}$. The decrease in amount of water from 100 to $60 \%$ did not decrease yield significantly $(\mathrm{p}<0.05)$. Similar experiment conducted by Tolga Erdem et al. (2010) on broccoli crop to evaluate the yield and quality of broccoli under different irrigation regimes, nitrogen applications and cultivation periods resulted there were statistical differences along nitrogen doses with respect to yield and yield components while there were statistically no significant differences in the yield and yield components among irrigation regimes.

Therefore, about 20-40\% water could be saved by modifying the crop coefficient values $\left(\mathrm{K}_{\mathrm{c}}\right)$ as per local crop and variety. The reasons for optimum yield in broccoli with $80 \%$ of $\mathrm{ET}_{\mathrm{c}}$ were that at this soil moisture content the crop was neither deficient in its water requirement nor incurred more expenditure like in 100 $\%$ of $\mathrm{ET}_{\mathrm{c}}$. The soil was kept near to field capacity

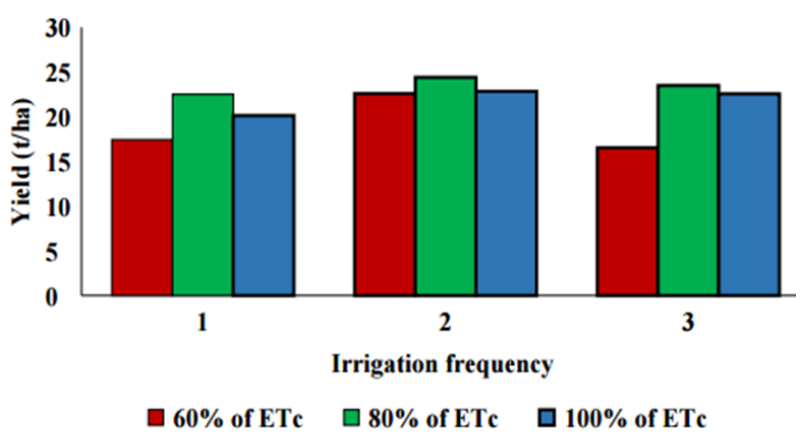

Fig. 5. Effect of different irrigation frequencies on broccoli yield.

resulted in low suction throughout the growing period in the root zone of broccoli and the marked reduction in curd yield in drip irrigation at 0.6.ETc was particularly due to water stress which were not fulfill the crop water requirement.

Statistical analysis of effect of different irrigation regimes on broccoli yield: It was observed that irrigation frequencies and amount of water significantly affected the crop yield (level of significance at 0.01 and 0.05). Analysis of variance for effect of irrigation frequencies and amount of irrigation water on broccoli yield is shown in Table $2 \& 3$ and proved that irrigation frequencies had more influence on crop yield in comparison to irrigation levels. From ANOVA tables it was observed that main and sub-plot treatments were significant at $1 \%$ level of significance whereas, interaction of main and subplots were significant at 5\% level of significance.

\section{Conclusion}

It was concluded that crop growth and yield were significantly affected under the different irrigation regimes. The maximum yield (24.46 t/ha) was obtained with $80 \%$ of $\mathrm{ET}_{\mathrm{c}}$ with once in 2 days irrigation followed by $100 \%$ of $\mathrm{ET}_{\mathrm{c}}$ with once in 2 days. Lowest yield $(16.53 \mathrm{t} / \mathrm{ha})$ was obtained at $60 \%$ of $\mathrm{ET}_{\mathrm{c}}$ at once in 3 days irrigation. The average yield of broccoli was recorded as $20.01,23.27$ and 20.86 t/ha for daily irrigation, once in 2, 3 days irrigation frequency, respectively. Experimental results in this study showed that the irrigation frequencies had more influence on crop yield in comparison to irrigation levels. The decrease in amount of water from 100 to $60 \%$ did not decrease yield significantly. Therefore, about 20-40 \% water could be saved by modifying the crop coefficient values $\left(\mathrm{K}_{\mathrm{c}}\right)$ as per local crop and variety. The reasons for optimum yield in broccoli with $80 \%$ of $\mathrm{ET}_{\mathrm{c}}$ were that at this soil moisture the crop was neither deficient in its water requirement nor incurred more expenditure like in $100 \%$ of $\mathrm{ET}_{\mathrm{c}}$. Statistical analysis showed that irrigation frequencies and amount of water both significantly affected the crop yield (level of significance at 0.01 and 0.05 ) but irrigation frequencies had more influence on crop yield in comparison to irrigation levels. This 
research suggests that irrigation scheduling on alternate day basis is an appropriate cycle for optimum yield of broccoli.

\section{REFERENCES}

Andrade, P., Aguera, J., Upadhyaya, S., Jenkins, B., Rosa, U. and Josiah, M. (1998). Evaluation of a dielectric-based moisture and salinity sensor for in-situ applications. In 2001 ASAE Annual Meeting (p. 1). American Society of Agricultural and Biological Engineers.

Anonymous, (2013). Ministry of Agriculture, Govt. of India www.moa.gov.jm

Brennan, E. B. (2016). Agronomy of strip intercropping broccoli with alyssum for biological control of aphids. Biological Control. 97:109-119.

Bhakare, B.D. and Fatkal, Y.D. (2008). Influence of micro irrigation and fertilizer levels through fertigation on growth, yield and quality of onion seed. Agricultural Water Management.16 (1):35-39.

Bora, N.J. and Babu, H.M. (2014). Drip irrigation and black polythene mulch pressure on development, yield and water use efficiency of tomato. International Journal of Irrigation and Water Management.1:1-4.

Chan, M. D., and Johnson, L.F.(2017).New Approaches to Irrigation Scheduling of Vegetables. Horticulturae. 3 (2): 28 .

Himanshu, S.K., Singh, A.K., Kumar S. and Kalura, P. (2013). Response of broccoli to irrigation scheduling and methods under drip, sprinkler and surface irrigation. International Journal of Engineering and $\mathrm{Ad}$ vanced Technology.2 (4):777-782.

Leib, B.G., Hattendorf, M., Elliot, T, and Mattews, G. (2002). Adoption and adaption of scientific irrigation scheduling: Trends from Washington, USA as of 1998. Agricultural Water Management. 55:105-102.

Soulis, K. X., Elmaloglou, S., and Dercas, N. 2015). Investigating the effects of soil moisture sensors positioning and accuracy on soil moisture based drip irrigation scheduling systems. Agricultural Water Management. 148:258-268.

Tavakkoli, A. and Oweis, T.Y. (2004). The role of supplemental irrigation and nitrogen in producing bread wheat in the highlands of Iran. Agricultural Water Management.65:225-236.

TERI (2015). Green growth and water sector in India. New Delhi: The Energy and Resources Institute.15pp. http:// www.teriin.org/

Tolga Erdem and Levent, Arm. (2010).Yield and quality response of drip irrigated broccoli (Brassica oleracea L.var. italica) under different irrigation regimes, nitrogen applications and cultivation periods. Agricultural Water Management.97:681-688.

Thentu, T. L., Dutta, D., Mudi, D.D. and Saha, A. (2016). Performance of broccoli (Brassica oleracea var. italica) under drip irrigation and mulch. Journal of Applied and Natural Science 8 (3): 1410 - 1415. 